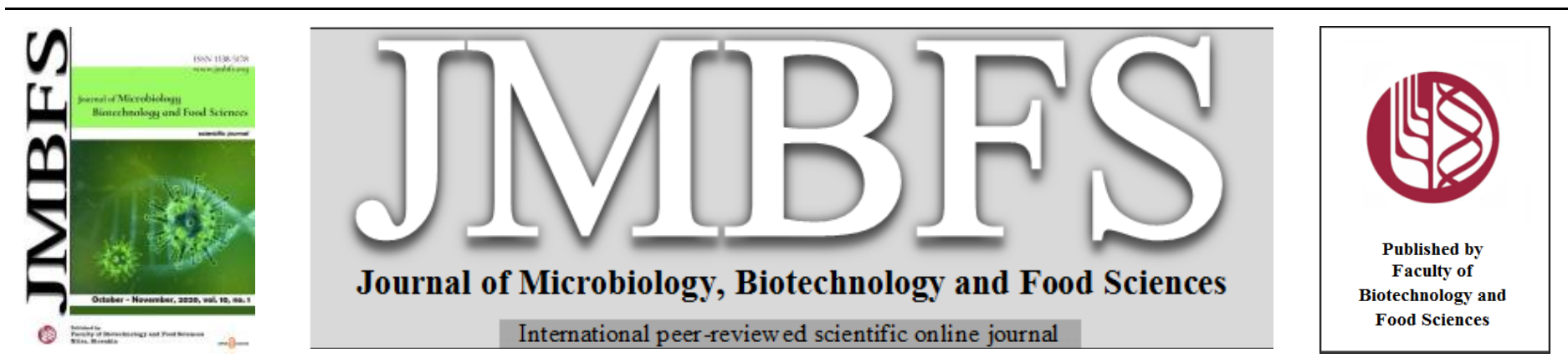

\title{
BIOREMEDIATION OF DIESEL CONTAMINATED SOIL USING BACTERIAL COCKTAIL AND ORGANIC NUTRIENTS
}

\author{
Ibrahim Osinowo, Olabisi Peter Abioye, Solomon Bankole Oyeleke, Oluwafemi Adebayo Oyewole
}

Address(es): Dr. Olabisi Peter Abioye,

${ }^{1}$ Federal University of Technology, School of Life Sciences, Department of Microbiology, Bosso Campus PMB 65, Minna, Nigeria, +2348140031875.

*Corresponding author: bisyem2603@yahoo.com

doi: 10.15414/jmbfs.2020.10.2.150-158

\section{ARTICLE INFO}

Received 9. 3. 2018

Revised 8. 5. 2020

Accepted 1.6. 2020

Published 1. 10. 2020

Regular article OPEN $\partial_{\text {ACCESS }}$

\begin{abstract}
Bioremediation is a process of contaminant degradation in the environment using microorganisms. Bioremediation of diesel contaminated soil was studied using bacterial cocktail and organic nutrients from cow dung and poultry droppings at interval of 21 days for a total period of 84 days. Two hundred grams $(200 \mathrm{~g})$ of soil were weighed into clay pots polluted with $10 \%(\mathrm{w} / \mathrm{w})$ diesel oil and left undisturbed for 48 hours in an open field. After 48 hours, the clay pots were inoculated with bacterial cocktail (two bacteria isolates from diesel contaminated soil), 10\% (w/w) of cow dung (CD), 10\% (w/w) of poultry droppings (PD) and 5\% (w/w) of sodium azide $\left(\mathrm{NaN}_{3}\right)$. The two bacterial isolates were identified as Micrococcus luteus trpE16 and Bacillus subtilis DNK UT 02 after screening for hydrocarbon utilization using standard methods. The counts of hydrocarbon utilizing bacteria (THB) in the amended soil ranged from $20.2 \times 10^{7}$ and $63.5 \times 10^{7} \mathrm{cfu} / \mathrm{g}$ while unamended soil had the least count of THB ranging between $8.4 \times 10^{7}$ and $19.0 \times 10^{7} \mathrm{cfu} / \mathrm{g}$. Soil bioremediated with bacterial cocktail $(\mathrm{BC})+10 \%(\mathrm{CD}+\mathrm{PD})$ recorded highest total petroleum hydrocarbon $(\mathrm{TPH})$ degradation of $48.76 \%, 56.32 \%, 72.89 \%$ and $96.80 \%$ at the end of days $21,42,63$ and 84 respectively while autoclaved soil with $5 \% \mathrm{NaN}_{3}$ recorded the least $(10.03 \%, 13.38 \%, 14.02 \%$ and $18.42 \%)$ respectively. First order kinetic model showed that soil bioremediated with BC with $10 \%(\mathrm{CD}+\mathrm{PD})$ recorded highest biodegradation rate constant of 0.2096 day $^{-1}$ and half-life of 3.31 days. Statistical analysis indicated that the results obtained were significantly $(P<0.05)$ different during the 84 days of this study. Amendment of diesel contaminated soil with bacterial cocktail and organic wastes caused changes in the soil physiochemical properties and accelerated the rate of biodegradation in the soil. However, poultry droppings and cow dung can serve as a potential and viable biostimulant for enhanced biodegradation of diesel in soil.
\end{abstract}

Keywords: Bioremediation, Micrococcus luteus, Bacillus subtilis, organic compound

\section{INTRODUCTION}

Over the years, the activities of Oil and Gas industry have turned out to be a threat to the environment due to the several occurrences of oil spillage into soil and water environment. Oil spillage has caused untold hardship on those residing in areas where this natural resource is in abundance, as it has deprived them of portable water being that the surface and ground water down the soil layers gets contaminated when the spillage occurs (Olabemiwo et al., 2014).

Diesel changes the physico-chemical properties of soil. It increases the level of toxins such as zinc and iron in the soil and reduces the amount of nutrients available. There is high accumulation of aluminium and manganese ions which are toxic to plant growth due to the anaerobic condition in the soil, the water logging and acid metabolites created by the diesel fuel. Furthermore, there is reduction in the amount of oxygen diffused to the root system if the oil is stranded on the plant shoot, thus affecting the soil indirectly (Ebere et al., 2011; Chen et al., 2015).

Due to high demand on land and water, it is imperative that the soil and water body affected by the diesel spillage has to be rehabilitated in time for uses. Therefore, natural methods like bush fallowing for soil cannot always be relied on. This has given rise to several techniques of remediation. Among the various techniques that have been utilized in replenishing soil nutrients over the years, bioremediation seems to be most thriving (Tariqet al., 2016).

Bioremediation is the process by which pollutants in the environment is converted into less toxic or non-toxic compounds, using naturally occurring microorganisms or genetically modified microorganisms. It is a natura degradation process by which microorganisms chemically alter or break down organic molecules into innocuous substances such as carbon dioxide, fatty acids and water in order to obtain energy and nutrients (Adaba, 2013).

Bioaugmentation and biostimulation are two approaches to bioremediation geared toward enhancing and speeding up the process. Bioaugmentation involves the addition of external microbial population (endogenous or exogenous) to the polluted site. Bacteria such as Bacillus sp, Micrococcus sp, Pseudomonas sp Streptomyces sp, Methanobacterium sp, Thiobacillus sp are the most common microbes used (Castro-Gutiérrez et al., 2012; Okoh, 2013). Biostimulation involves the addition of appropriate nutrients such as organic manure, inorganic fertilizers (NPK), provision of oxygen to a polluted site to increase microbial activities of indigenous microbial flora (Odu et al., 2015). Previous study (Ibiene et al., 2011), reported the use of cow dung and poultry droppings for bioremediation of hydrocarbon contaminated soil. However, to the best of my knowledge on literature search, there is little or no information on the use of bacteria cocktail with cow dung and poultry droppings.Therefore, the aim of this study was to remediate diesel contaminated soil using bacterial cocktail (containing Micrococcus luteusand Bacillus subtilis isolated from contaminated soil) and alongside cow dung and poultry droppings.

\section{MATERIALS AND METHODS}

\section{Collection of samples}

Soil sample was collected from $0-10 \mathrm{~cm}$ depth using soil auger from mechanic workshop beside Bosso primary school Minna and brought to Microbiology Department Federal University of Technology Minna. Diesel was purchased from Filling Station in Bosso, Minna Niger State. Cow dung and poultry droppings were collected from animal farm and poultry farm in Bosso Minna, Niger State.

\section{The isolation of microorganisms}

The aerobic heterotrophic bacteria were isolated from soil sample in mechanic workshop using methods described by (Henrick, 2004) while mineral salt medium (MSM) in the soil was used to enumerate the hydrocarbon-utilizing bacteria (HUB). The mineral salt medium contains $1.8 \mathrm{~g} \mathrm{~K}_{2} \mathrm{HPO}_{4}, 4.0 \mathrm{~g} \mathrm{NH}_{4} \mathrm{Cl}$, $0.2 \mathrm{~g} \mathrm{MgSO}_{4} .7 \mathrm{H}_{2} \mathrm{O}, 1.2 \mathrm{~g} \mathrm{KH}_{2} \mathrm{PO}_{4}, 0.01 \mathrm{~g} \mathrm{FeSO}_{4} .7 \mathrm{H}_{2} \mathrm{O}, 0.1 \mathrm{~g} \mathrm{NaCl}, 20 \mathrm{~g}$ agar, 
$1 \%$ diesel (as the only carbon source) in one liter of deionized water. The $\mathrm{pH}$ was adjusted to 7.4 with $0.1 \mathrm{M} \mathrm{NaOH}$. The oil agar plates were inoculated with $0.1 \mathrm{~mL}$ of serially diluted soil samples $\left(10^{-3}\right)$ and were incubated at $30^{\circ} \mathrm{C}$ for five days and observed. The identities of the isolates were determined by comparing their characteristics with those of known taxa as described in Bergy's manual of determinative bacteriology. All chemicals (analytical grade) were purchased from Sigma-Aldrich, St Louis, MO, USA.

\section{Screening of bacterial isolates for biodegradation potential}

Nutrient broth was prepared and $9 \mathrm{~mL}$ of the broth wasdispensed into test tubes and autoclaved. The colonies of the pure isolates were inoculated into the test tubes containing the broth and incubated at $37^{\circ} \mathrm{C}$ for 24 hours. Mineral Salt medium (broth) was prepared by adding $1.2 \mathrm{~g} \mathrm{KH}_{2} \mathrm{PO}_{4}, 1.8 \mathrm{~g} \mathrm{~K}_{2} \mathrm{HPO}_{4}, 4.0 \mathrm{~g}$ $\mathrm{NH}_{4} \mathrm{Cl}, 0.2 \mathrm{~g} \mathrm{MgSO}_{4} .7 \mathrm{H}_{2} \mathrm{O}, 0.1 \mathrm{~g} \mathrm{NaCl}$ and $0.01 \mathrm{~g} \mathrm{FeSO}_{4} .7 \mathrm{H}_{2} \mathrm{O}$ in one liter of deionized water. The prepared broth $(100 \mathrm{~mL})$ was mixed with $0.1 \%$ of diesel as the only source of carbon and autoclaved. When cooled, $1 \mathrm{~mL}$ of the tes organisms in the nutrient broth was transferred into test tubes containing $9 \mathrm{~mL}$ of the sterile mixtures (MSM broth and diesell), and were incubated at $37^{\circ} \mathrm{C}$ for 5 days. At the end of incubation, a UV spectrophotometer (model 752 Guang-Zhou Co. Ltd, China) was used to determine the optical density at $620 \mathrm{~nm}$ wavelength The best bacterial isolates were selected for the cocktail used for the bioremediation process.

\section{Preparation of inoculums for bioremediation}

The two bacterial isolates that recorded higher hydrocarbon degradation were inoculated into bijou bottles, each containing $5 \mathrm{~mL}$ of nutrient broth and were incubated at $37^{\circ} \mathrm{C}$ for 24 to 48 hours. The microbial count was carried out by measuring absorbance using a spectrophotometer at an absorbance of $560 \mathrm{~nm}$ wavelengths, until a cell concentration of $1.5 \times 10^{7}$ colony forming units (cfu) $/ \mathrm{mL}$ (McFarland Standard) was achieved. The $5 \mathrm{~mL}$ culture was transferred into 1 liter sterile nutrient broth and incubated at $37^{\circ} \mathrm{C}$ for 24 hours. The bacteria cocktail was prepared by mixing equal volumes $(500 \mathrm{~mL})$ of the culture of the above cell concentration of each isolate.

\section{Microcosm set up}

Complete Randomized Block Design (CRBD) was used in this study. Two hundred (200) grams of air-dried soil sieved with 2-mm mesh size was placed in clay pots polluted with $10 \%$ w/w diesel and left undisturbed for 48 hours. After 48 hours, treatment one was diesel polluted soil without any amendment with 10 $\mathrm{mL}$ of cell concentration $1.5 \times 10^{7} \mathrm{cfu} / \mathrm{mL}$ bacterial cocktail and $10 \%$ of each organic wastes (cow dung and poultry droppings) serve as control, Treatment two: diesel polluted soil $+10 \mathrm{~mL}$ of broth culture of bacterial cocktail, Treatment three: diesel polluted soil $+10 \mathrm{~mL}$ of broth culture of bacterial cocktail $+10 \%$ (w/w) of cow dung, Treatment four: diesel polluted soil $+10 \mathrm{~mL}$ of broth culture of bacterial cocktail $+10 \%(\mathrm{w} / \mathrm{w})$ of poultry droppings, Treatment five: diese polluted soil $+10 \mathrm{~mL}$ of broth culture of bacterial cocktail $+10 \%(\mathrm{w} / \mathrm{w})$ of cow dung and poultry droppings, Treatment six: diesel polluted soil $+10 \%(\mathrm{w} / \mathrm{w})$ of cow dung, Treatment seven: diesel polluted soil $+10 \%(\mathrm{w} / \mathrm{w})$ of poultry dropping, Treatment eight: autoclaved soil $+10 \%(\mathrm{w} / \mathrm{w})$ diesel $+5 \%$ sodium azide $\left(\mathrm{NaN}_{3}\right)$ (to eliminate all life forms during bioremediation process) and was thoroughly mixed as shown in Table 1 . The moisture content was adjusted to $60 \%$ water holding capacity and set up under natural environment exposed to sunlight and at room temperature $28^{\circ} \mathrm{C} \pm 2$. The content of each vessel was mixed twice a week for aeration, and the moisture content was maintained at $60 \%$ water holding capacity by addition of sterile distilled water. This experiment was set up in duplicate.

Table 1 Experimental layout for bioremediation

$\begin{array}{ll}\text { Design } & \text { Treatment } \\ \mathbf{A} & 200 \mathrm{~g} \text { of Soil }+10 \% \text { diesel (Control) } \\ \text { B } & 200 \mathrm{~g} \text { of Soil }+10 \% \text { diesel oil }+10 \mathrm{~mL} \text { of } \mathrm{BC} \\ \mathbf{C} & 200 \mathrm{~g} \text { of Soil }+10 \% \text { diesel oil }+10 \mathrm{~mL} \text { of } \mathrm{BC}+10 \% \mathrm{PD} \\ \mathbf{D} & 200 \mathrm{~g} \text { of Soil }+10 \% \text { diesel oil }+10 \mathrm{~mL} \text { of } \mathrm{BC}+10 \% \mathrm{CD} \\ \mathbf{E} & 200 \mathrm{~g} \text { of Soil }+10 \% \text { diesel oil }+10 \mathrm{~mL} \text { of } \mathrm{BC}+10 \%(\mathrm{PD}+\mathrm{CD}) \\ \mathbf{H} & 200 \mathrm{~g} \text { of Autoclaved soil }+10 \% \text { diesel oil }+5 \% \mathrm{NaN}_{3}\end{array}$

Key $\mathrm{BC}=$ bacterial cocktail (two bacterial isolates from diesel contaminated soil); $\mathrm{PD}=$ Poultry dropping; $\mathrm{CD}=$ Cow dung: $\mathrm{NaN}_{3}=$ Sodium azide

Determination of physicochemical properties of soil (unpolluted \& polluted) and organic wastes

Soil $\mathrm{pH}$ was determined with $\mathrm{pH}$ meter (Model 511) on 1:2.5 (w/v) soil/ distilled water after 30 minutes equilibration. The content of nitrogen in the soil and organic wastes utilized for bioremediation was determined using the Kjeldah method, and the contents of phosphorus and carbon were determined using ICP
OES and furnace method, respectively. Moisture content was determined using the gravimetric method.

\section{Microbial counts}

Changes in microbial population were determined by inoculating $0.1 \mathrm{~mL}$ of serially diluted soil sample onto nutrient and diesel oil agar for total heterotrophic and hydrocarbon utilizing bacteria counts respectively. The nutrient agar plates were incubated at $37^{\circ} \mathrm{C}$ for $24 \mathrm{hrs}$ and diesel oil agar plates at $37^{\circ} \mathrm{C}$ for 5 days The colonies developed after incubation were counted and expressed as colony forming units per gram $(\mathrm{cfu} / \mathrm{g})$ of soil sample.

\section{Total petroleum hydrocarbon determination}

Gravimetric method was used to determine the hydrocarbon content of the soil samples using tuolene cold extraction method described by Adesodun and Mbagwu (2008). This was done by adding $10 \mathrm{~g}$ of soil sample into $20 \mathrm{~mL}$ of toluene (Analar grade). The mixture was shaken for 30 minutes using an orbital shaker and the supernatant was measured using spectrophotometer at $420 \mathrm{~nm}$. To determine the total petroleum hydrocarbon in the soil, values were estimated with reference to standard curve obtained from new diesel oil diluted with toluene. The total petroleum hydrocarbon data was fitted to first-order kinetics model of Yeung et al. (1997) as follows: $\mathrm{y}=\mathrm{ae}^{-\mathrm{kt} .}$ In this equation, $\mathrm{y}$ is the residual soil hydrocarbon content $\left(\mathrm{g} \mathrm{kg}^{-1}\right)$, a is the soil initial hydrocarbon content $\left(\mathrm{g} \mathrm{kg}^{-1}\right), \mathrm{k}$ is the biodegradation rate constant $\left(\mathrm{day}^{-1}\right)$, and $\mathrm{t}$ is the treatment time. Half- life was calculated as: Half life $=1 \mathrm{n}(2) / k$. The assumption in this model was that the rate of hydrocarbons degradation positively correlated with the soil hydrocarbon pool size (Yeung et al., 1997)

\section{Gas chromatographic mass- spectrophotometric analysis of diesel extract}

Gas chromatography - Mass spectroscopy analysis of the diesel extracts from the soil samples was analyzed using GC-MS model 7890A with Mass Selective Detector model: 5975C (MSD). The diesel oil extraction was carried out by dissolving $5 \mathrm{~g}$ of the soil samples in $10 \mathrm{~mL}(99.99 \%)$ pure dichloromethane in a well corked reagent bottle. This was thoroughly mixed using an ultra sonicator for a period of five hours. The mixture was allowed to stand for 72 hours and filtered into a beaker; the mixture was rewashed with $20 \mathrm{~mL}$ dichloromethane for two more consecutive times. The combined aliquots was evaporated on a steam berth to $5 \mathrm{~mL}$ and filtered through a pipette stocked with glass wool (membrane) with packed anhydrous sodium sulfate silica gel to remove the left over moisture and other impurities. The filtrate was concentrated to $1 \mathrm{~mL}$ in the vial bottle and was analyzed on Gas chromatography.

\section{Statistical analysis of data}

The data generated from this study was subjected to analysis of variance $(\mathrm{P} \leq 0.05)$ using SPSS version 20 and the averages were compared by Duncan Multiple Range Tests (DMRT) $\mathrm{P} \leq 0.05$. The effect of studied factors were considered significant when $\mathrm{P} \leq 0.05$.

\section{RESULTS}

\section{Physicochemical properties of soil (unpolluted) and the organic waste}

The physicochemical properties of soil and organic wastes that were used for bioremediation are presented in Table 2 .

Table 2 The physicochemical properties of soil and organic wastes

Parameter Soil Organic wastes

\begin{tabular}{lccc}
\cline { 3 - 4 } & & $\mathrm{CD}$ & $\mathrm{PD}$ \\
\hline $\mathrm{pH}$ & $6.70 \pm 0.25$ & $7.10 \pm 0.19$ & $7.40 \pm 0.25$ \\
Nitrogen (\%) & $0.34 \pm 0.02$ & $0.74 \pm 0.01$ & $3.26 \pm 0.25$ \\
Phosphorus $\left(\mathrm{mgkg}^{-1}\right)$ & $23.80 \pm 1.52$ & $35.37 \pm 2.42$ & $87.58 \pm 0.25$ \\
Organic C (\%) & $1.30 \pm 0.09$ & $2.79 \pm 0.20$ & $6.82 \pm 0.25$ \\
Moisture (\%) & $8.20 \pm 0.10$ & $36.20 \pm 3.15$ & $15.40 \pm 0.25$ \\
Sand (\%) & $44.24 \pm 3.67$ & - & - \\
Silt (\%) & $30.28 \pm 2.29$ & - & - \\
Clay (\%) & $25.48 \pm 1.09$ & - & - \\
Texture & Sandy loam & - & - \\
\hline
\end{tabular}

Key: $\mathrm{CD}=$ Cow dung, $\mathrm{PD}=$ Poultry dropping

\section{Nutrients Composition of bioremediated soil}

The $\mathrm{pH}$ of the bioremediated soils ranged from 7.1 to 7.8 during the 84 days study period. Soil bioremediated with bacterial cocktail (BC) with $10 \%$ poultry droppings $(\mathrm{PD})+\mathrm{Cow}$ dung $(\mathrm{CD})$ recorded highest $\mathrm{pH}$ of 7.8 while autoclaved 
remediated soil with $5 \%$ sodium azide $\left(\mathrm{NaN}_{3}\right)$ recorded the least $\mathrm{pH}$ of 7.1 as shown in Fig. 1

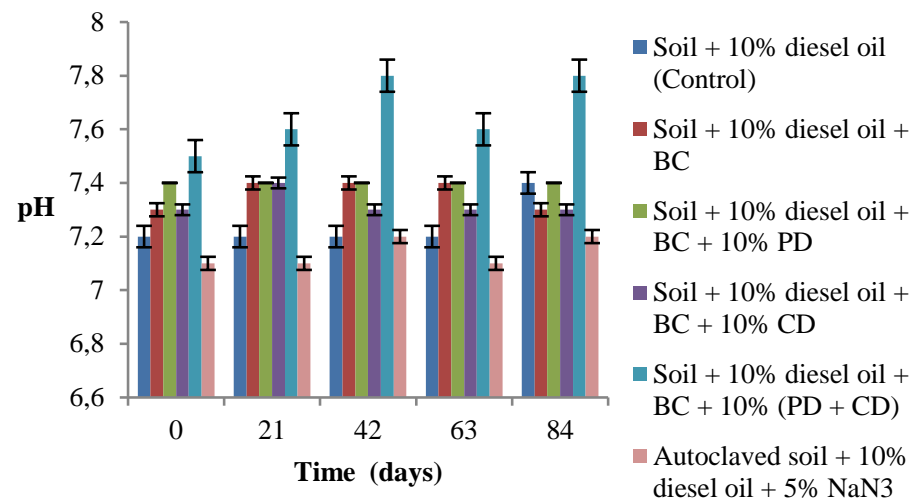

Figure $1 \mathrm{pH}$ values of diesel contaminated soil during bioremediation

The minerals (nitrogen, phosphorus, and carbon) content in all experimental soil decreases with increase in bioremediation time (Fig. 2-4). However, the autoclaved remediated soil with $5 \%$ sodium azide $\left(\mathrm{NaN}_{3}\right)$ had the highes nitrogen $(3.59 \pm 0.21-3.42 \pm 0.02 \%$ ) while unamended soil (control) had the leas $(0.85 \pm 0.02 \%)$ on day zero $(0)$ whereas soil bioremediated with bacterial cocktail had the least $(0.43 \pm 0.02 \%)$ on the last day (day 84$)$. Also, soil bioremediated with bacterial cocktail $(\mathrm{BC})+10 \%$ Poultry droppings $(\mathrm{PD})+$ Cow dung $(\mathrm{CD})$ had the highest phosphorus $(39.84 \pm 0.67 \mathrm{mg} / \mathrm{kg})$ on day zero (0) whereas autoclaved control soil with $5 \%\left(\mathrm{NaN}_{3}\right)$ had the highest phosphorus $(24.00 \pm 0.26$ $\mathrm{mg} / \mathrm{kg}$ ) on the last day (day 84) meanwhile unamended soil (control) had the least phosphorus $(23.56 \pm 0.47-14.62 \pm 0.45 \mathrm{mg} / \mathrm{kg})$ content. The highest organic carbon content was observed in soil bioremediated with $\mathrm{BC}+10 \% \mathrm{PD}+\mathrm{CD}$ $(3.61 \pm 0.04 \%)$ on day zero whereas autoclaved control soil with $5 \%\left(\mathrm{NaN}_{3}\right)$ had the highest organic carbon $(2.07 \pm 0.02 \%)$ on day 84 meanwhile remediated control soil had the least organic carbon $(1.90 \pm 0.02-1.03 \pm 0.05 \%)$.

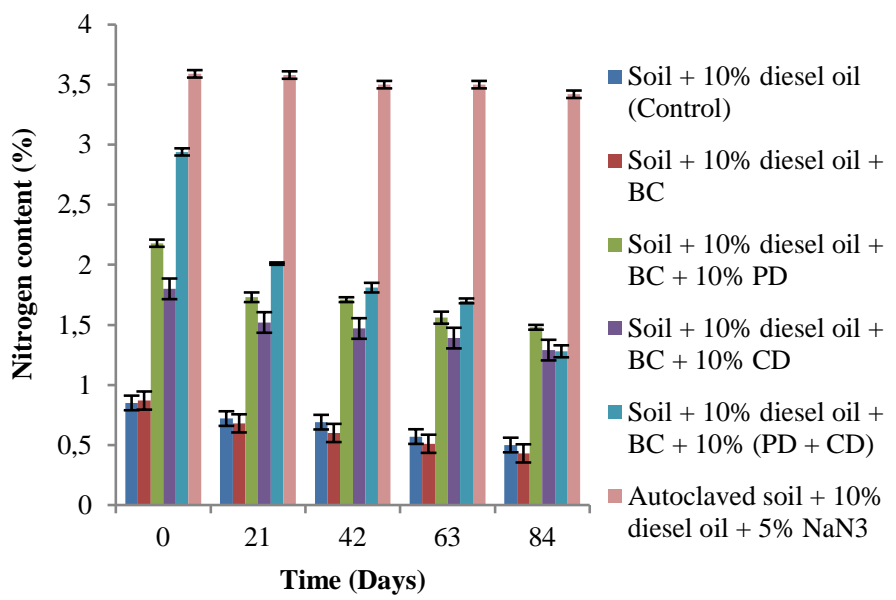

Figure 2 Nitrogen contents of diesel contaminated soil during bioremediation

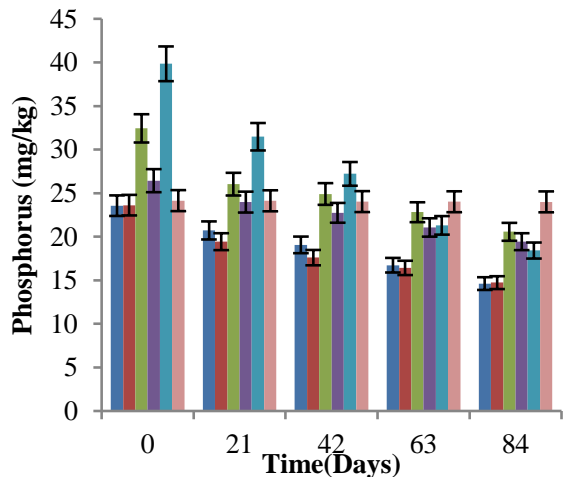

Soil $+10 \%$ diesel oil (Control)

$\square$ Soil $+10 \%$ diesel oil + $\mathrm{BC}$

Soil $+10 \%$ diesel oil + $\mathrm{BC}+10 \% \mathrm{PD}$

- Soil $+10 \%$ diesel oil + $\mathrm{BC}+10 \% \mathrm{CD}$

Soil $+10 \%$ diesel oil + $\mathrm{BC}+10 \%(\mathrm{PD}+\mathrm{CD})$

Autoclaved soil $+10 \%$ diesel oil $+5 \%$ NaN3

Figure 3 Phosphorus contents of diesel contaminated soil during bioremediation

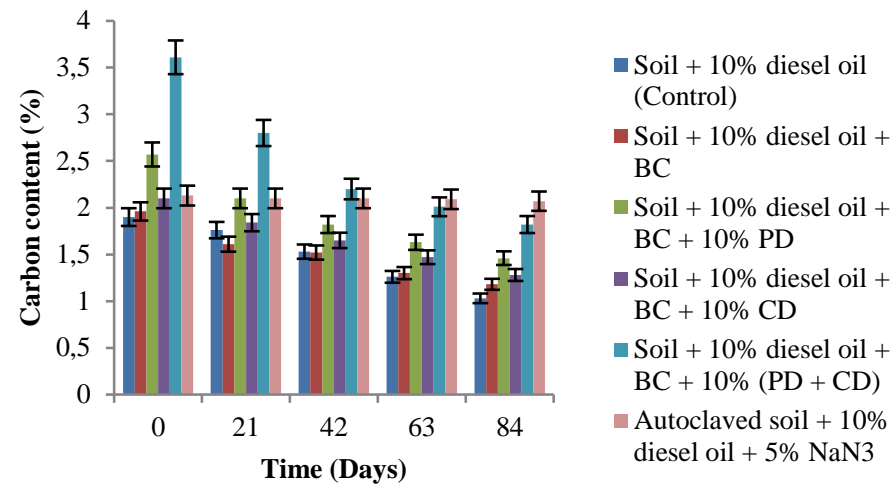

Figure 4 Carbon contents of diesel contaminated soil during bioremediation

\section{Microbial counts}

The counts of total heterotrophic bacteria (THB) in all experimental soil increased with increase in bioremediation time. However, soil bioremediated with bacterial cocktail $(\mathrm{BC})+10 \%$ poultry droppings $(\mathrm{PD})+$ cow dung $(\mathrm{CD})$ had the highest THB (between $20.2 \times 10^{7}$ and $63.5 \times 10^{7} \mathrm{cfu} / \mathrm{g}$ ) while unamended soil (control) had the least count of THB $\left(8.4 \times 10^{7}\right.$ and $\left.19.0 \times 10^{7} \mathrm{cfu} / \mathrm{g}\right)$ (Fig. 5). Similarly, soil bioremediated with $\mathrm{BC}+10 \%(\mathrm{PD}+\mathrm{CD})$ had the highest hydrocarbon utilizing bacteria (HUB) ranging between $15.4 \times 10^{6}$ and $86.4 \times 10^{6}$ $\mathrm{cfu} / \mathrm{g}$, while the autoclaved remediated soil with $5 \% \mathrm{NaN}_{3}$ had the least $\left(1.00 \times 10^{6}\right.$ cfu/g) as shown in Fig. 6.

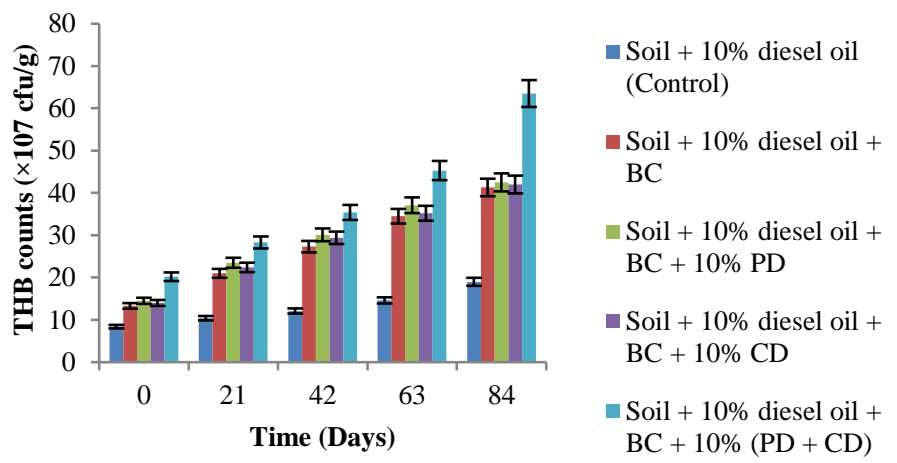

Figure 5 Total heterotrophic bacteria (THB) count in diesel contaminated soil during bioremediation

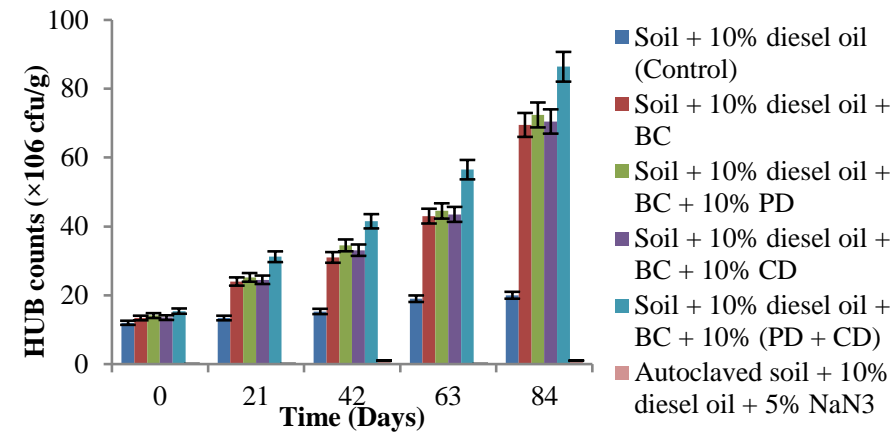

Figure 6 Hydrocarbon-utilizing bacterial (HUB) counts in diesel contaminated soil during bioremediation

\section{Biodegradation of diesel oil}

The biodegradation rate of diesel during the period of study is presented in Fig 7 There was a progressive decline in total petroleum hydrocarbon during the process of remediation in all the soil bioremediated with the cow dung and poultry droppings compared to that of unamended soil and autoclaved remediated soil with $5 \% \quad \mathrm{NaN}_{3}$. Soil bioremediated with bacterial cocktail $(\mathrm{BC})+10 \%$ Poultry droppings (PD) + Cow dung (CD) had the highest total petroleum hydrocarbon (TPH) degradation of $48.76 \%, 56.32 \%, 72.89 \%$ and $96.80 \%$ at the end of days 21, 42, 63 and 84 respectively while soil remediated with $5 \% \mathrm{NaN}_{3}$ had the least TPH degradation of $10.03 \%, 13.38 \% 14.02 \%$ and $18.42 \%$ at the end of days $21,42,63$ and 84 respectively. 


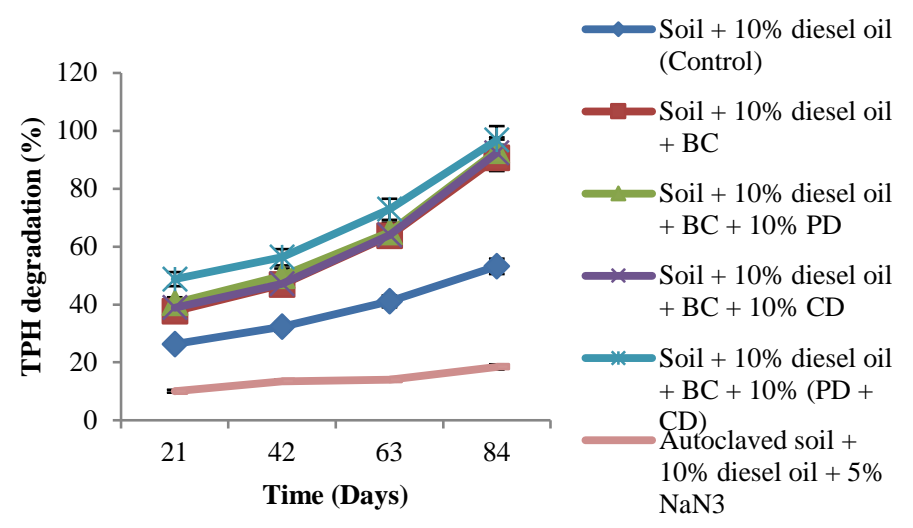

Figure 7 Total petroleum hydrocarbon degradation in diesel contaminated soil during bioremediation

\section{Net percentage loss of diesel contaminated soil}

The efficiency of bioremediation was investigated by determining the net $\%$ loss of diesel oil in contaminated soil. Soil remediated with $\mathrm{BC}+10 \%(\mathrm{PD}+\mathrm{CD}) \mathrm{had}$ the highest net percentage loss of $22.44 \pm 0.30 \%, 24.05 \pm 0.49 \%, 31.83 \pm 0.30 \%$ and $43.62 \pm 0.65 \%$ at the end of days $21,42,63$ and 84 respectively. The least net percentage loss of diesel oil of $11.33 \pm 0.25 \%, 14.59 \pm 0.20 \%, 22.70 \pm 0.33 \%$ and $37.46 \pm 0.02 \%$ was recorded for soil remediated with $\mathrm{BC}$ at the end of days 21 42,63 and 84 (Table 2).

Table 2 Net percentage loss of total petroleum hydrocarbon in diesel contaminated soil

\begin{tabular}{lcccc}
\hline Treatment & \multicolumn{4}{c}{ Time (days) } \\
\cline { 2 - 5 } & $\mathbf{2 1}$ & $\mathbf{4 2}$ & $\mathbf{6 3}$ & $\mathbf{8 4}$ \\
\hline $\begin{array}{l}\text { Soil + 10\% } \\
\text { diesel oil + BC }\end{array}$ & $11.33 \pm 0.25$ & $14.59 \pm 0.20$ & $22.70 \pm 0.33$ & $37.46 \pm 0.02$ \\
$\begin{array}{l}\text { Soil + 10\% } \\
\text { diesel oil + BC }\end{array}$ & $14.16 \pm 0.23$ & $17.66 \pm 0.20$ & $23.98 \pm 0.25$ & $39.90 \pm 0.55$ \\
$+10 \%$ PD & & & & \\
Soil + 10\% & & & & \\
diesel oil + BC & $12.54 \pm 0.22$ & $14.83 \pm 0.40$ & $22.89 \pm 0.20$ & $39.18 \pm 0.25$ \\
$+10 \%$ CD & & & & \\
Soil + 10\% & & & & \\
diesel oil + BC & $22.44 \pm 0.30$ & $24.05 \pm 0.49$ & $31.83 \pm 0.30$ & $43.62 \pm 0.65$ \\
$+10 \%$ (PD + & & & & \\
CD) & & & & \\
\hline
\end{tabular}

Key: $\mathrm{BC}$ = bacterial cocktail (two bacterial isolates from diesel polluted soil),PD $=$ Poultry droppings $\mathrm{CD}=$ Cow dung

\section{Biodegradation rate constant and half-life}

The biodegradation rate constant $(\mathrm{k})$ and half-life $\left(\mathrm{t}_{1 / 2}\right)$ for the different treatments within the 84 days of study is shown in Table 3 . Soil remediated with $\mathrm{BC}+10 \%$ $(\mathrm{PD}+\mathrm{CD})$ shows the highest biodegradation rate of $0.2096 \mathrm{day}^{-1}$ and least halflife of 3.31 days; while autoclaved soil $+10 \%$ diesel oil $+5 \% \mathrm{NaN}_{3}$ had the least biodegradation rate of $0.0097 \mathrm{day}^{-1}$ and highest half-life of 71.46 days. However, the biodegradation rate of unamended soil (control) was 0.0916 day $^{-1}$ and halflife of 7.57 days.

Table 3 Biodegradation rate and half-life of hydrocarbon in diesel contaminated soil

\begin{tabular}{llll}
\hline Treatment & $\begin{array}{l}\text { Biodegradation } \\
\text { rate constant } \\
\text { day }^{-1}\end{array}$ & $\begin{array}{l}\text { Half- life } \\
\text { days }\end{array}$ & $\left(\mathrm{t}_{1 / 2}\right)$ \\
\hline Soil + 10\% diesel oil (Control) & 0.0916 & 7.57 \\
$\begin{array}{l}\text { Soil + 10\% diesel oil + BC } \\
\text { Soil + 10\% diesel oil + BC + 10\% }\end{array}$ & 0.1732 & 4.00 \\
PD & 0.1848 & 3.75 \\
Soil + 10\% diesel oil + BC + 10\% & 0.1772 & 3.91 \\
$\begin{array}{l}\text { CD } \\
\text { Soil + 10\% diesel oil + BC + 10\% }\end{array}$ & 0.2096 & 3.31 \\
$\begin{array}{l}\text { PD + CD) } \\
\begin{array}{l}\text { Autoclaved soil + 10\% diesel oil } \\
+5 \% \text { NaN }\end{array}\end{array}$ & 0.0097 & 71.46
\end{tabular}

Key: $\mathrm{BC}=$ bacterial cocktail (two bacterial isolates from diesel polluted soil),PD $=$ Poultry droppings $\mathrm{CD}=$ Cow dung

\section{Gas chromatography and mass spectroscopy}

Gas Chromatography and Mass Spectroscopy (GCMS) analysis revealed a total number of 67 individual hydrocarbons in undegraded diesel oil (Fig. 8) consisting of n-alkane of carbon chain $\left(\mathrm{C}_{9}-\mathrm{C}_{31}\right)$, carboxylic acid $\left(\mathrm{C}_{2} \mathrm{H}_{3} \mathrm{O}-\mathrm{C}_{23} \mathrm{H}_{44} \mathrm{O}_{3}\right)$, naphthalene, akyl group of naphthalene $\left(\mathrm{C}_{10} \mathrm{H}_{8}-\mathrm{C}_{15} \mathrm{H}_{28}\right)$, aromatic and polycyclic aromatic compounds at different peak numbers, retention time and percentage Area or height of abundance using 60 percent match quality NIST library (1999) as shown in Table 4.

Soil bioremediated with bacterial cocktail $(\mathrm{BC})+10 \%$ poultry dropping $(\mathrm{PD})$ and cow dung (CD) had the highest reduction in the hydrocarbon compounds (Fig. 9) in which the odd molecular number of n- alkane $\left(\mathrm{C}_{11}-\mathrm{C}_{31}\right)$ except $\mathrm{C}_{23}$, carboxylic acid $\left(\mathrm{C}_{2} \mathrm{H}_{3} \mathrm{O}-\mathrm{C}_{23} \mathrm{H}_{44} \mathrm{O}_{3}\right)$, naphthalene, akyl group of naphthalene $\left(\mathrm{C}_{10} \mathrm{H}_{8}-\right.$ $\mathrm{C}_{15} \mathrm{H}_{28}$ ), aromatic and polycyclic aromatic compounds had been degraded at the end of the study period (Table 5). There is also a significant reduction in individual hydrocarbons with soil bioremediated with $\mathrm{BC}+10 \%$ PD (Fig. 10) having degraded a total number of 48 out 67 individual hydrocarbons identified in undegraded diesel oil. Individual hydrocarbon like decane $\left(\mathrm{C}_{10}\right)$, undecane $\left(C_{11}\right)$, dodecane $\left(C_{12}\right)$, pentadecane $\left(C_{15}\right)$ at different peak numbers $1,6,11,12$, respectively (saturated alkane), nonyl vinyl ester $\left(\mathrm{C}_{12} \mathrm{H}_{22} \mathrm{O}\right)$ (carboxylic acid), 4,6,8-Trimethylazulene $\left(\mathrm{C}_{13} \mathrm{H}_{14}\right)$ (polycyclic aromatic compound) at peak numbers 4,19 and many more compounds had been degraded. However, soil bioremediated with $\mathrm{BC}+10 \% \mathrm{CD}$ (Fig. 11) had more higher molecular number of n-alkane $\left(\mathrm{C}_{36}-\mathrm{C}_{54}\right)$, carboxylic acid $\left(\mathrm{C}_{2} \mathrm{H}_{3} \mathrm{O}-\mathrm{C}_{23} \mathrm{H}_{44} \mathrm{O}_{3}\right)$, aromatic and polycyclic aromatic compounds than soil bioremediated with $\mathrm{BC}+10 \% \mathrm{PD}$ but degraded all naphthalene and akyl group of naphthalene $\left(\mathrm{C}_{10} \mathrm{H}_{8}-\mathrm{C}_{15} \mathrm{H}_{28}\right)$ as shown in Tables 6-7.

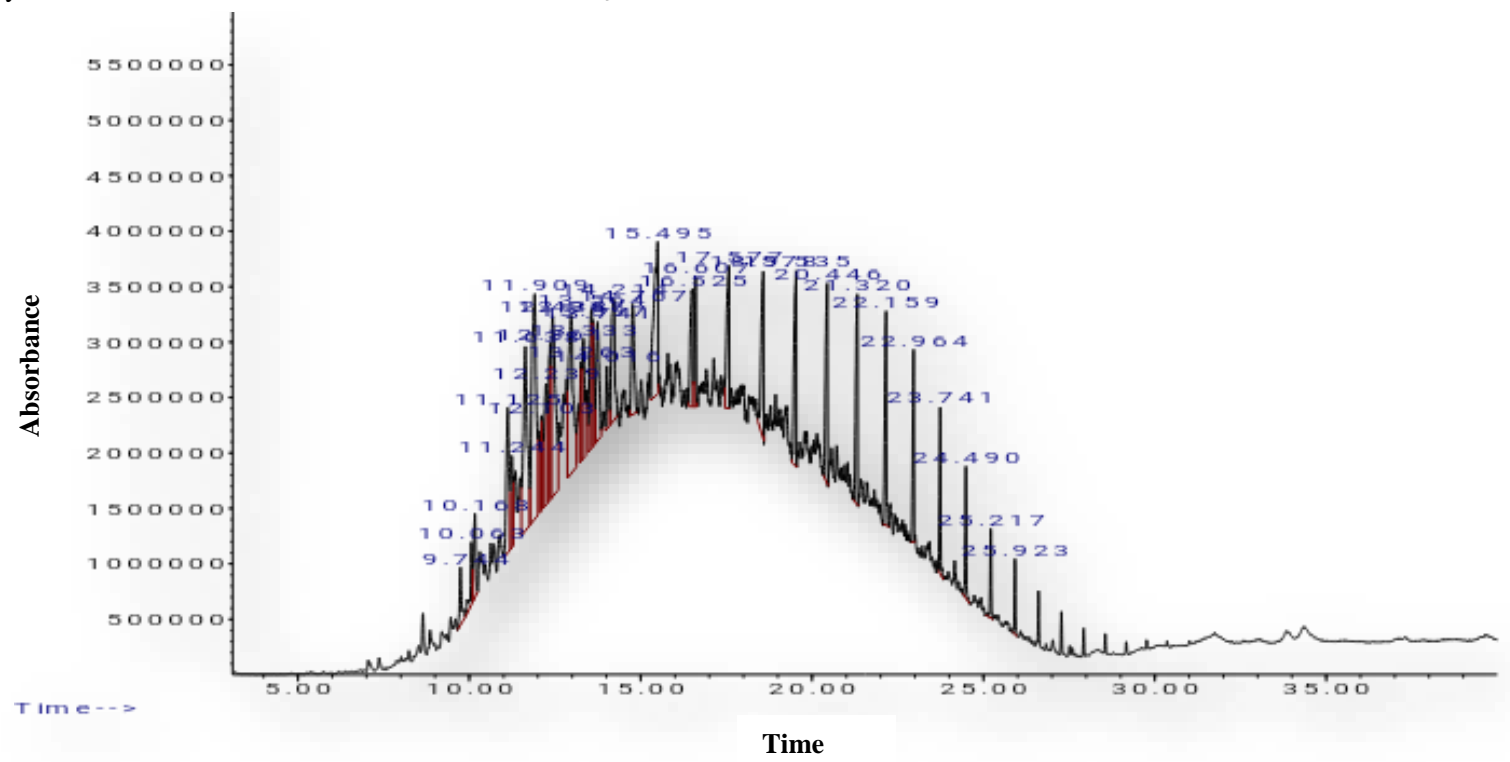

Figure 8 Chromatogram charts of undegraded diesel oil used for bioremediation 
Table 4 Individual hydrocarbon identified in undegraded diesel oil

\begin{tabular}{|c|c|c|c|c|c|c|}
\hline $\mathbf{S} / \mathbf{N}$ & PK & RT & \%AREA & COMPOUNDS & M.F & M.Q \\
\hline 1 & 1 & 9.741 & 0.98 & Dodecane, 4,6-dimethyl- & $\mathrm{C}_{12} \mathrm{H}_{26}$ & 87 \\
\hline 2 & & & & Hexadecane, 2,6,11,15-tetramethyl- & $\mathrm{C}_{18} \mathrm{H}_{32}$ & 93 \\
\hline 3 & & & & Nonane, 3,7-dimethyl- & $\mathrm{C}_{13} \mathrm{H}_{32}$ & 91 \\
\hline 4 & 2 & 10.062 & 1.08 & Naphthalene, 2-methyl- & $\mathrm{C}_{10} \mathrm{H}_{8}$ & 97 \\
\hline 5 & 3 & 10.165 & 1.46 & Tridecane & $\mathrm{C}_{14} \mathrm{H}_{31}$ & 86 \\
\hline 6 & & & & Undecane & $\mathrm{C}_{11} \mathrm{H}_{24}$ & 75 \\
\hline 7 & & & & Carbonic acid, nonyl vinyl ester & $\mathrm{CH}_{2} \mathrm{CO}_{3}$ & 69 \\
\hline 8 & 4 & 11.126 & 3.60 & Decahydro-1,1,4a,5,6-pentamethyl naphthalene & $\mathrm{C}_{15} \mathrm{H}_{28}$ & 91 \\
\hline 9 & & & & Neopentylidenecyclohexane & $\mathrm{C}_{11} \mathrm{H}_{20}$ & 89 \\
\hline 10 & & & & Bicyclo[3.1.1]heptane, 2,6,6-trimethyl- & $\mathrm{C}_{7} \mathrm{H}_{12}$ & 92 \\
\hline 11 & 5 & 11.246 & 1.63 & Dodecane, 2,6,11-trimethyl- & $\mathrm{C}_{12} \mathrm{H}_{26}$ & 90 \\
\hline 12 & & & & Docosyl pentyl ether & $\mathrm{C}_{10} \mathrm{H}_{20} \mathrm{O}$ & 87 \\
\hline 13 & 6 & 11.635 & 6.50 & Tetradecane & $\mathrm{C}_{14} \mathrm{H}_{30}$ & 89 \\
\hline 14 & & & & Decane & $\mathrm{C}_{10} \mathrm{H}_{22}$ & 91 \\
\hline 15 & 7 & 11.910 & 8.67 & Naphthalene, 2,6-dimethyl- & $\mathrm{C}_{10} \mathrm{H}_{8}$ & 97 \\
\hline 16 & 8 & 12.105 & 0.97 & Naphthalene, 2,7-dimethyl- & $\mathrm{C}_{12} \mathrm{H}_{14}$ & 89 \\
\hline 17 & 9 & 12.242 & 2.94 & 6-Octen-1-ol, 3,7-dimethyl-, (R)- & $\mathrm{C}_{10} \mathrm{H}_{20} \mathrm{O}$ & 94 \\
\hline 18 & & & & 2-Octen-1-ol, 3,7-dimethyl- & $\mathrm{C}_{10} \mathrm{H}_{20} \mathrm{O}$ & 95 \\
\hline 19 & & & & Citronellol & $\mathrm{C}_{11} \mathrm{H}_{23} \mathrm{O}$ & 93 \\
\hline 20 & 10 & 12.362 & 3.34 & Decahydro-1,1,4a,5,6-pentamethylnaphthalene & $\mathrm{C}_{15} \mathrm{H}_{28}$ & 87 \\
\hline 21 & & & & 2-Anthracenamine & $\mathrm{C}_{14} \mathrm{H}_{11} \mathrm{~N}$ & 69 \\
\hline 22 & & & & Benzo[f]quinoline, 3-methyl- & $\mathrm{C}_{13} \mathrm{H}_{9} \mathrm{~N}$ & 84 \\
\hline 23 & 11 & 12.436 & 6.46 & Dodecane, 2,6,11-trimethyl- & $\mathrm{C}_{5} \mathrm{H}_{11} \mathrm{O}_{3}$ & 87 \\
\hline 24 & & & & Carbonic acid, eicosyl vinyl ester & $\mathrm{C}_{23} \mathrm{H}_{44} \mathrm{O}_{3}$ & 91 \\
\hline 25 & & & & Undecane & $\mathrm{C}_{11} \mathrm{H}_{24}$ & 89 \\
\hline 26 & 12 & 12.969 & 6.64 & Dodecane & $\mathrm{C}_{12} \mathrm{H}_{26}$ & 65 \\
\hline 27 & & & & Pentadecane & $\mathrm{C}_{15} \mathrm{H}_{32}$ & 82 \\
\hline 28 & & & & Methoxyacetic acid, 2-tridecyl ester & $\mathrm{C}_{3} \mathrm{H}_{6} \mathrm{O}_{3}$ & 87 \\
\hline 29 & 13 & 13.260 & 1.10 & Naphthalene, 1,6,7-trimethyl- & $\mathrm{C}_{10} \mathrm{H}_{8}$ & 89 \\
\hline 30 & & & & 3-(2-Methyl-propenyl)-1H-indene & $\mathrm{C}_{17} \mathrm{H}_{27}$ & 92 \\
\hline 31 & 14 & 13.335 & 2.88 & Naphthalene, 1,4,6-trimethyl- & $\mathrm{C}_{13} \mathrm{H}_{17}$ & 83 \\
\hline 32 & 15 & 13.564 & 3.04 & Naphthalene, 1,6,7-trimethyl- & $\mathrm{C}_{13} \mathrm{H}_{17}$ & 96 \\
\hline 33 & 16 & 13.598 & 1.80 & Naphthalene, 1,6,7-trimethyl- & $\mathrm{C}_{13} \mathrm{H}_{17}$ & 96 \\
\hline 34 & & & & 4,6,8-Trimethylazulene & $\mathrm{C}_{13} \mathrm{H}_{14}$ & 89 \\
\hline 35 & 17 & 13.741 & 3.13 & 4,6,8-Trimethylazulene & $\mathrm{C}_{13} \mathrm{H}_{14}$ & 89 \\
\hline 36 & & & & Naphthalene, 2,3,6-trimethyl- & $\mathrm{C}_{10} \mathrm{H}_{8}$ & 92 \\
\hline 37 & 18 & 14.016 & 1.18 & Naphthalene, 2,3,6-trimethyl- & $\mathrm{C}_{13} \mathrm{H}_{17}$ & 91 \\
\hline 38 & & & & 4,6,8-Trimethylazulene & $\mathrm{C}_{13} \mathrm{H}_{14}$ & 79 \\
\hline 39 & 19 & 14.216 & 3.77 & Hexadecane & $\mathrm{C}_{16} \mathrm{H}_{34}$ & 75 \\
\hline 40 & 20 & 14.765 & 2.67 & Hentriacontane & $\mathrm{C}_{31} \mathrm{H}_{64}$ & 83 \\
\hline 41 & & & & Methoxyacetic acid, 2-tridecyl ester & $\mathrm{C}_{3} \mathrm{H}_{6} \mathrm{O}_{3}$ & 67 \\
\hline 42 & & & & Tetradecane & $\mathrm{C}_{14} \mathrm{H}_{30}$ & 83 \\
\hline 43 & 21 & 15.498 & 5.48 & Dodecane, 2,6,11-trimethyl- & $\mathrm{C}_{12} \mathrm{H}_{26}$ & 78 \\
\hline 44 & & & & Octadecane, 2,6-dimethyl- & $\mathrm{C}_{21} \mathrm{H}_{42}$ & 92 \\
\hline 45 & & & & Pentadecane, 2,6,10,14-tetramethyl & $\mathrm{C}_{17} \mathrm{H}_{34}$ & 91 \\
\hline 46 & 22 & 16.522 & 2.96 & Octadecane & $\mathrm{C}_{18} \mathrm{H}_{38}$ & 89 \\
\hline 47 & 23 & 16.608 & 1.71 & Dodecane, 2,6,10-trimethyl- & $\mathrm{C}_{10} \mathrm{H}_{22}$ & 94 \\
\hline 48 & & & & Hexadecane, 2,6,10,14-tetramethyl- & $\mathrm{C}_{19} \mathrm{H}_{42}$ & 69 \\
\hline 49 & & & & $2,6,10$-Trimethyltridecane & $\mathrm{C}_{16} \mathrm{H}_{36}$ & 87 \\
\hline 50 & 24 & 17.575 & 3.17 & Nonadecane & $\mathrm{C}_{19} \mathrm{H}_{40}$ & 91 \\
\hline 51 & 25 & 18.576 & 3.28 & Eicosane & $\mathrm{C}_{20} \mathrm{H}_{42}$ & 94 \\
\hline 52 & & & & Octadecane, 2-methyl- & $\mathrm{C}_{18} \mathrm{H}_{38}$ & 97 \\
\hline 53 & 26 & 19.537 & 3.73 & Heneicosane & $\mathrm{C}_{22} \mathrm{H}_{42}$ & 89 \\
\hline 54 & 27 & 20.447 & 3.28 & Docosane & $\mathrm{C}_{22} \mathrm{H}_{46}$ & 78 \\
\hline 55 & 28 & 21.323 & 3.16 & Tricosane & $\mathrm{C}_{23} \mathrm{H}_{48}$ & 65 \\
\hline 56 & & & & Hexacosane & $\mathrm{C}_{26} \mathrm{H}_{54}$ & 91 \\
\hline 57 & 29 & 22.158 & 2.94 & Tetracosane & $\mathrm{C}_{24} \mathrm{H}_{50}$ & 87 \\
\hline 58 & 30 & 22.965 & 2.10 & Pentacosane & $\mathrm{C}_{25} \mathrm{H}_{52}$ & 68 \\
\hline 59 & 31 & 23.743 & 1.61 & Hexadecane, 2,6,10,14-tetramethyl- & $\mathrm{C}_{26} \mathrm{H}_{54}$ & 93 \\
\hline 60 & 32 & 24.493 & 1.22 & Hexadecane, 1 -iodo- & $\mathrm{C}_{29} \mathrm{H}_{68}$ & 91 \\
\hline 61 & & & & Heptadecane & $\mathrm{C}_{17} \mathrm{H}_{36}$ & 79 \\
\hline 62 & 33 & 25.219 & 0.86 & Octacosane & $\mathrm{C}_{28} \mathrm{H}_{58}$ & 92 \\
\hline 63 & & & & Hexadecane, 1-iodo- & $\mathrm{C}_{16} \mathrm{H}_{34}$ & 97 \\
\hline 64 & & & & 3-Eicosene, (E)- & $\mathrm{C}_{20} \mathrm{H}_{32}$ & 85 \\
\hline 65 & 34 & 25.923 & 0.66 & Hexadecane, 1-iodo- & $\mathrm{C}_{16} \mathrm{H}_{34}$ & 91 \\
\hline 66 & & & & Octadecane, 1 -iodo- & $\mathrm{C}_{18} \mathrm{H}_{38}$ & 84 \\
\hline 67 & & & & 1-Octadecene & $\mathrm{C}_{18} \mathrm{H}_{37} 11$ & 67 \\
\hline
\end{tabular}

Key: PK= Peak number, RT= Retention time, M.F=Molecular formula, M.Q=Match Quality 


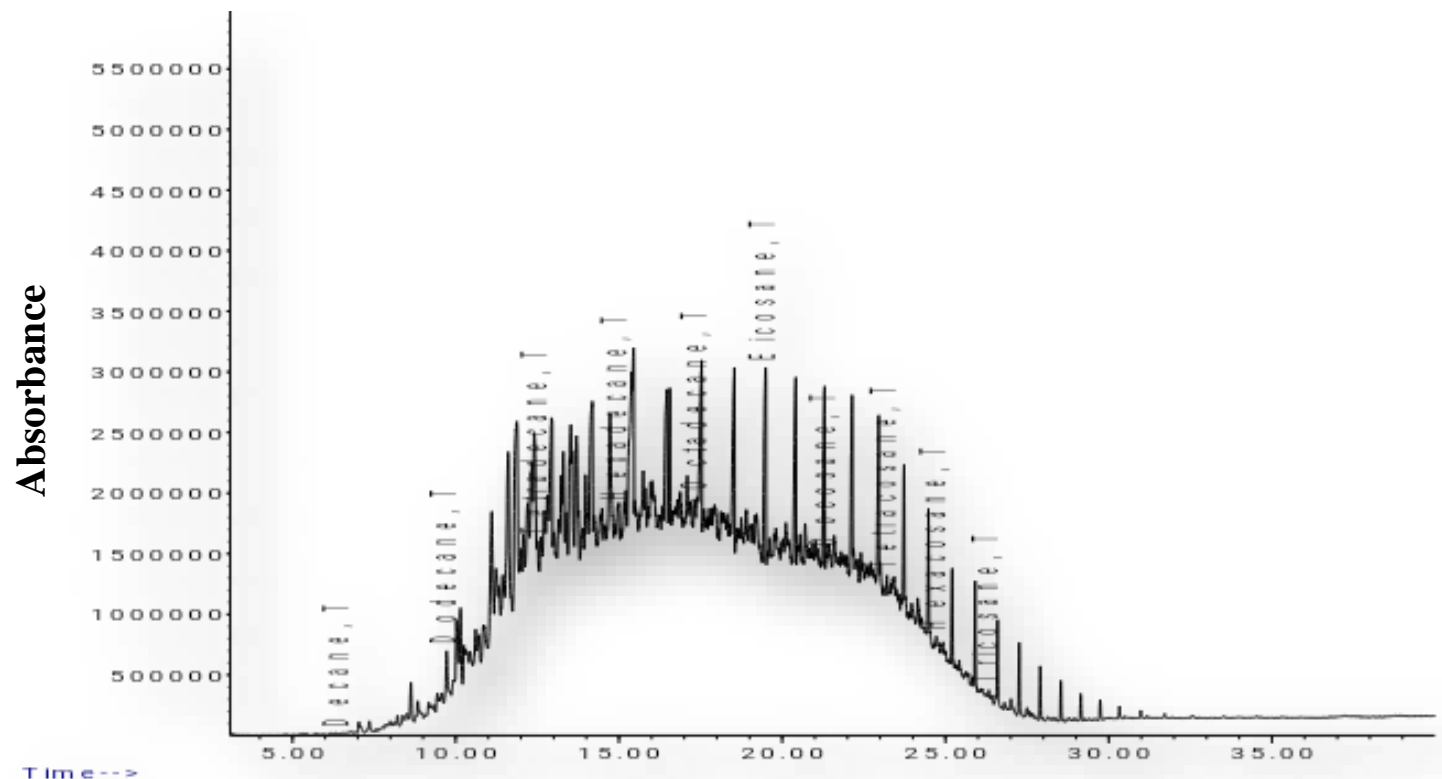

Time

Figure 9 Chromatogram of diesel contaminated soil remediated with bacterial cocktail $+10 \%$ cow dung + poultry dropping after of 84 days

Table 5 Individual hydrocarbon identified in diesel contaminated soil remediated with $\mathrm{BC}+10 \%(\mathrm{PD}+\mathrm{CD})$

\begin{tabular}{cccclll}
\multicolumn{2}{c}{ after of 84 days } & \multicolumn{1}{l}{ ( } \\
\hline S/N & PK & R & \% Area & COMPOUNDS & M. F & M.Q \\
\hline 1 & 1 & 6.428 & 0.03 & Decane & $\mathrm{C}_{10} \mathrm{H}_{22}$ & 91 \\
2 & 2 & 9.724 & 3.32 & Dodecane & $\mathrm{C}_{12} \mathrm{H}_{26}$ & 89 \\
3 & 3 & 12.505 & 1.17 & Tetradecane & $\mathrm{C}_{14} \mathrm{H}_{30}$ & 93 \\
4 & 4 & 14.954 & 1.06 & Hexadecane & $\mathrm{C}_{16} \mathrm{H}_{34}$ & 85 \\
5 & 5 & 17.403 & 1.35 & Octadecane & $\mathrm{C}_{18} \mathrm{H}_{38}$ & 69 \\
6 & 6 & 19.497 & 8.62 & Eicosane & $\mathrm{C}_{20} \mathrm{H}_{42}$ & 92 \\
7 & 7 & 21.346 & 0.39 & Docosane & $\mathrm{C}_{22} \mathrm{H}_{44}$ & 63 \\
8 & 8 & 23.205 & 0.62 & Tetracosane & $\mathrm{C}_{24} \mathrm{H}_{50}$ & 87 \\
9 & 9 & 24.716 & 0.33 & Hexacosane & $\mathrm{C}_{26} \mathrm{H}_{54}$ & 79 \\
10 & 10 & 26.329 & 0.15 & Tricosane & $\mathrm{C}_{23} \mathrm{H}_{48}$ & 65
\end{tabular}

Key: $\mathrm{BC}=$ bacterial cocktail (two bacterial isolates from diesel polluted soil), $\mathrm{CD}=\mathrm{Cow}$ dung

$\mathrm{PD}=$ Poultry dropping $\mathrm{PK}=$ Peak number, $\mathrm{RT}=$ Retention time, M.F=Molecular formualar, M.Q=Mash Quality

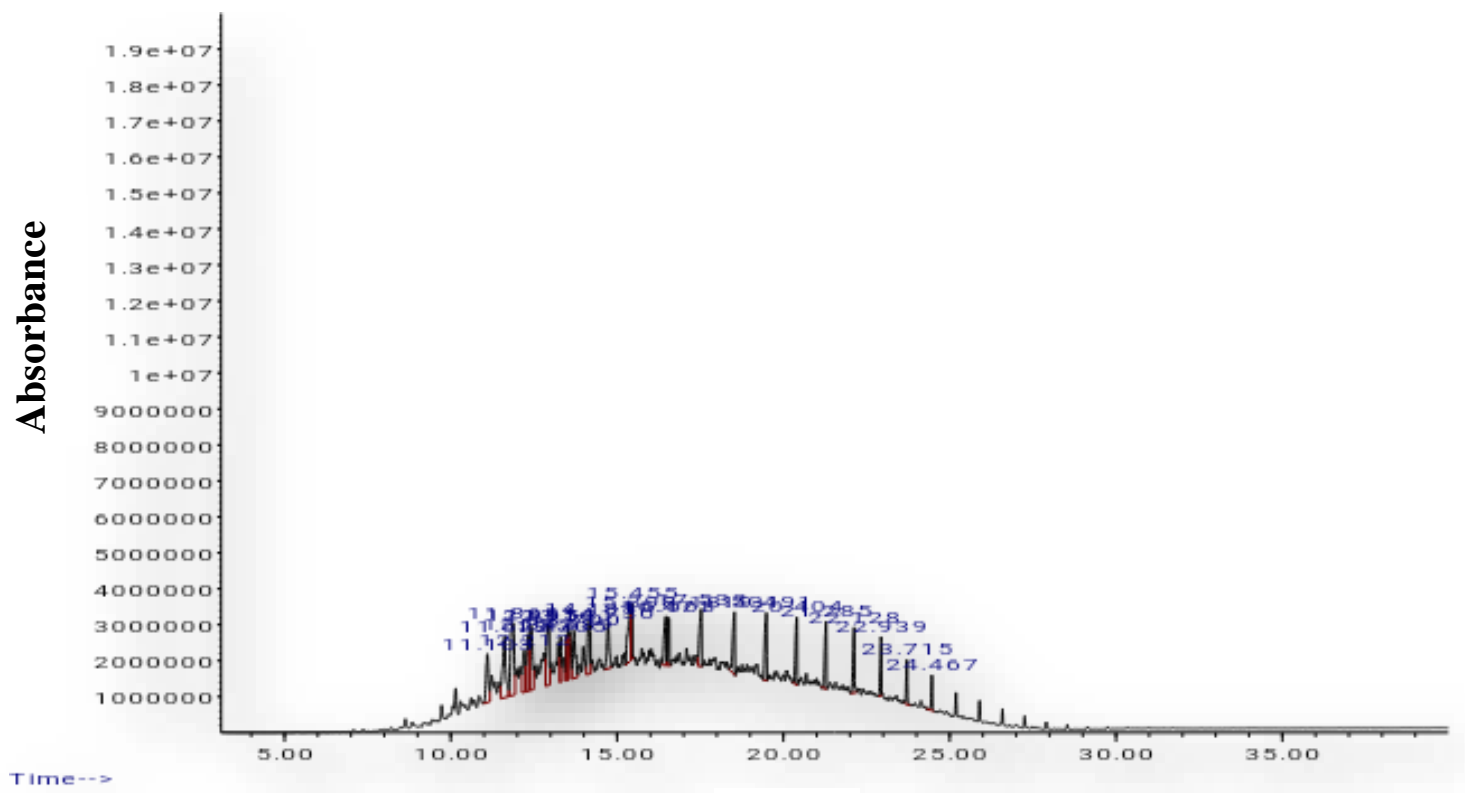

Time

Figure 10 Chromatogram of diesel contaminated soil remediated with bacterial cocktail + 10\%poultry dropping after of 84 days 


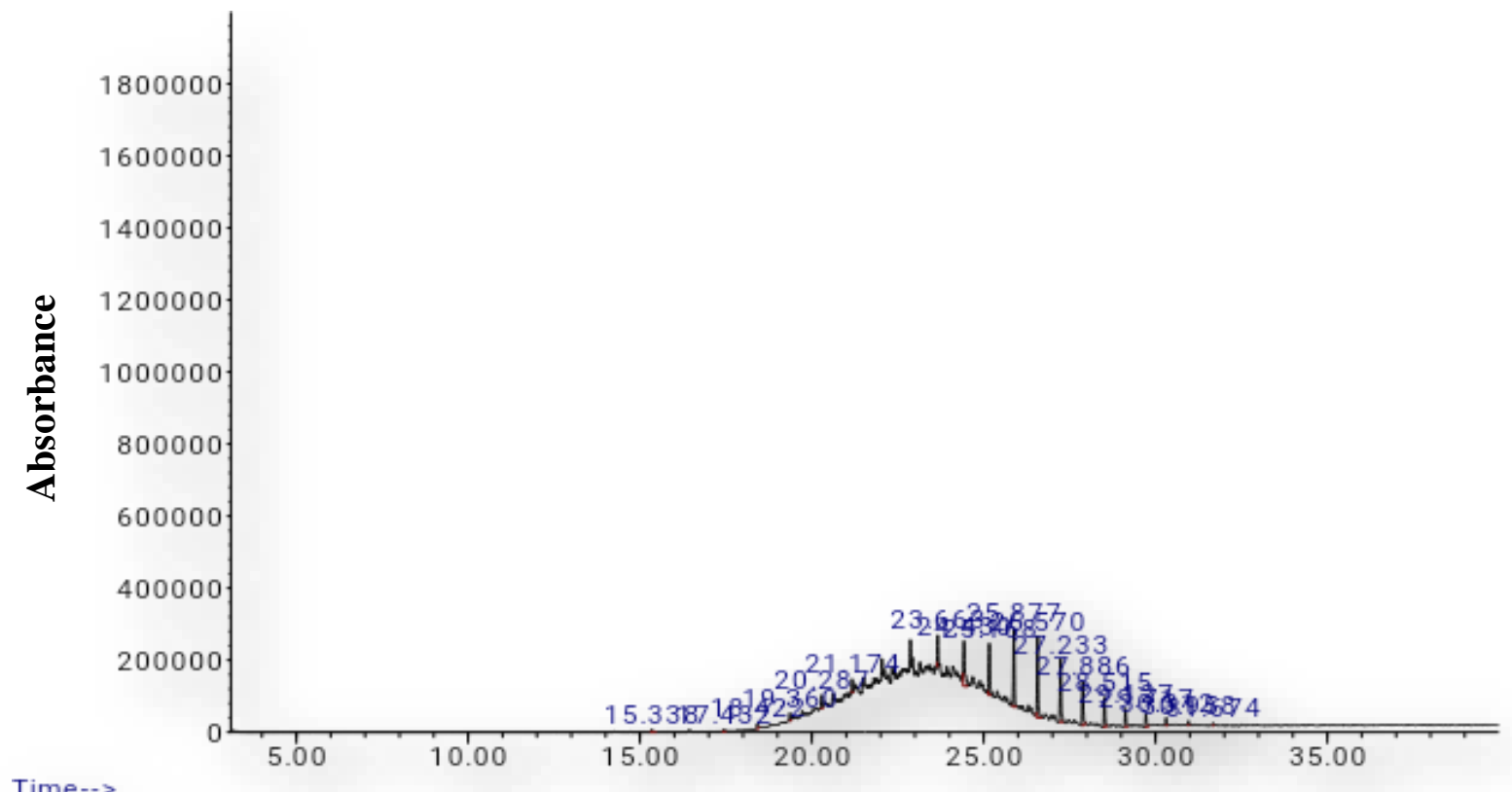

Time

Figure 11 Chromatogram of diesel contaminated soil remediated with bacterial cocktail $+10 \%$ cow dung after of 84 days

Table 6 Individual hydrocarbon identified in diesel contaminated soil remediated with BC + 10\% PD after of 84 days

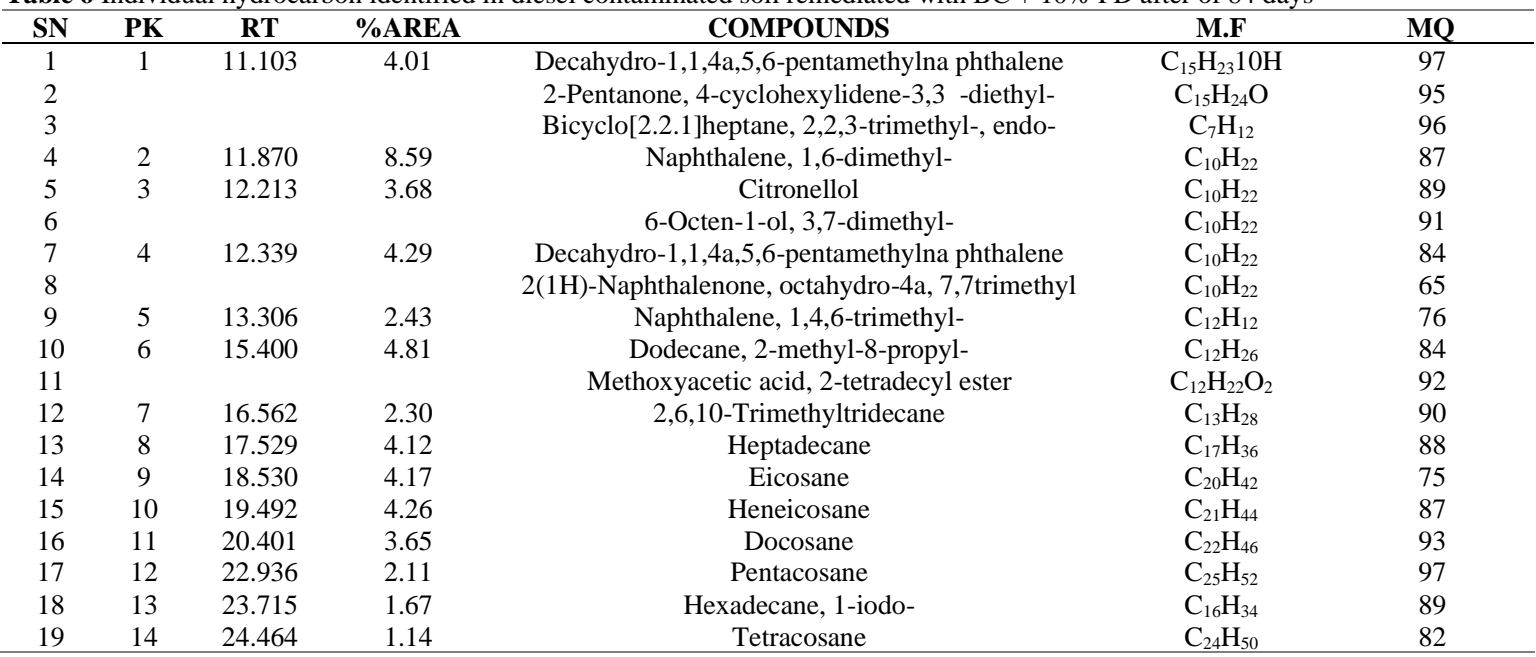

Key: $\mathrm{BC}=$ bacterial cocktail (two bacterial isolates from diesel polluted soil), $\mathrm{PD}=$ Poultry dropping, $\mathrm{PK}=\mathrm{Peak}$ number, $\mathrm{RT}=\mathrm{Retention}$ time, M.F=Molecular formualar, M.Q=Match Quality

Table 7 Individual hydrocarbon identified in diesel contaminated soil remediated with BC $+10 \%$ CD after of 84 days

\begin{tabular}{|c|c|c|c|c|c|c|}
\hline $\mathbf{S} / \mathbf{N}$ & PK & RT & \%AREA & COMPOUNDS & M.F & M.Q \\
\hline 1 & 1 & 15.338 & 1.04 & 1-Heptadecanamine & $\mathrm{C}_{17} \mathrm{H}_{37} \mathrm{~N}$ & 79 \\
\hline 2 & & & & Carbonic acid, prop-1-en-2-yltridecyl ester & $\mathrm{CH}_{2} \mathrm{CO}_{3}$ & 67 \\
\hline 3 & 2 & 17.432 & 0.69 & 1-Octanol, 2-butyl- & $\mathrm{C}_{8} \mathrm{H}_{18} \mathrm{O}$ & 91 \\
\hline 5 & 3 & 18.422 & 1.32 & Sulfurous acid, pentadecyl 2-propy 1 ester & $\mathrm{H}_{2} \mathrm{SO}_{3}$ & 93 \\
\hline 6 & 4 & 19.360 & 1.42 & Oxalic acid, cyclobutyl pentadecyl ester & $\mathrm{C}_{21} \mathrm{H}_{38} \mathrm{O}_{4}$ & 69 \\
\hline 7 & 5 & 20.287 & 2.42 & Docosyl isobutyl ether & $\mathrm{C}_{16} \mathrm{H}_{34} \mathrm{O}$ & 94 \\
\hline 10 & 8 & 26.570 & 15.78 & Triacontane & $\mathrm{C}_{30} \mathrm{H}_{62}$ & 91 \\
\hline 11 & & & & Docosane, 9-octyl- & $\mathrm{C}_{22} \mathrm{H}_{46}$ & 87 \\
\hline 12 & 9 & 27.233 & 12.63 & 3-Eicosene, (E)- & $\mathrm{C}_{20} \mathrm{H}_{40}$ & 83 \\
\hline 13 & & & & Heptacosane, 1-chloro- & $\mathrm{C}_{27} \mathrm{H}_{56}$ & 69 \\
\hline 14 & 10 & 27.886 & 8.20 & Tritetracontane & $\mathrm{C}_{43} \mathrm{H}_{88} \mathrm{Cl}$ & 87 \\
\hline 19 & & & & Sulfurous acid, 2-propyl tetradecyl ester & $\mathrm{C}_{12} \mathrm{H}_{26}$ & 87 \\
\hline 20 & 13 & 30.958 & 0.92 & Octadecane & $\mathrm{C}_{18} \mathrm{H}_{38}$ & 85 \\
\hline 21 & 14 & 31.674 & 0.51 & Cyclotrisiloxane, hexamethyl- & $\mathrm{C}_{36} \mathrm{H}_{78} \mathrm{O}_{3}$ & 93 \\
\hline
\end{tabular}

Key: $\mathrm{BC}=$ bacterial cocktail (two bacterial isolates from diesel polluted soil), $\mathrm{CD}=$ Cow dung, $\mathrm{PK}=\mathrm{Peak}$ number, $\mathrm{RT}=\mathrm{Retention}$ time, M.F=Molecular formular, M.Q=Match Quality 


\section{DISCUSSION}

Species of Micrococcus, Bacillus, Rhodococcus, Staphylococcus, and Pseudomonas have been reported by different authors in hydrocarbon degradation (Abioye et al., 2010; Dadrasnia and Agamuthu 2013). Of all the isolates identified, Micrococcus luteus strain trpE16 and Bacillus subtilis strain DNK UT 02 demonstrated higher ability in utilizing hydrocarbon when inoculated directly into mineral salt medium (broth) containing diesel oil as the sole source of carbon and energy (results not shown). This may be due to the ability of these organisms to secrete hydrocarbon degradative enzymes and catabolic genes for hydrocarbon degradation (Abioye et al., 2010; Dadrasnia and Agamuthu 2013; Nwogu, et al., 2015).

The $\mathrm{pH}$ of the soil indicates that the soil was alkaline in nature. Soil bioremediated with bacterial cocktail (BC) with $10 \%$ poultry droppings (PD) + Cow dung (CD) recorded highest $\mathrm{pH}$ of 7.8 while autoclaved remediated soil with $5 \%$ sodium azide $\left(\mathrm{NaN}_{3}\right)$ recorded least $\mathrm{pH}$ of 7.1 . This might be a factor that contributes to the high bacteria counts recorded in this study because bacteria survives and develops within this $\mathrm{pH}$ range than any other microorganisms.

Studies have reported that microbial growth in soil is controlled not by the total amount of resource available but by the scarcest resources (limiting factor), which are, in this case, Nitrogen $(\mathrm{N})$ and Phosphorus $(\mathrm{P})$ (Akpoveta et al., 2011; Gorban et al., 2011; Abioye et al., 2012). In this study, the soil bioremediated with bacterial cocktail $(\mathrm{BC})+10 \%$ cow dung and poultry droppings $(\mathrm{PD}+\mathrm{CD})$ had the second highest nitrogen $(2.94 \pm 0.19 \%)$, highest phosphorus $(39.84 \pm 0.67$ $\mathrm{mg} / \mathrm{kg})$ and carbon $(3.61 \pm 0.04 \%)$ content than others in the bio-remediated soil samples. These nutrients $(\mathrm{N}, \mathrm{P}$ and $\mathrm{C}$ ) in the appropriate ratio favored the proliferation of hydrocarbon-utilizing bacteria in the bio-remediated soil which in turn increase total petroleum hydrocarbon (TPH) degradation. This observation is in agreement with previous studies that reported enhanced degradation of crude oil using other animal manures such as goat manure (Nwogu, et al., 2015), poultry manure (Odu et al., 2015). However, the autoclaved control soil with $5 \%$ $\mathrm{NaN}_{3}$ that recorded highest amount nitrogen content $(3.59 \pm 0.21-3.42 \pm 0.02 \%)$ throughout the study period. The increase in nitrogen content is due to the addition of $\mathrm{NaN}_{3}$ which is a nitrogenous compound. This neither favored nor stifled the activities of the hydrocarbon-utilizing bacteria (HUB) in the remediated soil. This may be due to the antimicrobial activities of $\mathrm{NaN}_{3}$ which limit the growth and biodegradative activities of HUB in soil (Rahmoun et al., 2013)

The HUB counts in all amended bioremediated soils were gave a higher coun when compared to the control, this result is in agreement with Abioye et al. (2010) who reported the count of $\times 10^{6} \mathrm{cfu} / \mathrm{g}$ for hydrocarbon degraders in used oil polluted soil. This is found to be higher than those obtained by Nwogu, et al (2015) who reported a count of $\times 10^{5} \mathrm{cfu} / \mathrm{g}$ for HUB in hydrocarbon contaminated soil; this could be as a result of differences in adaptability and ecological nature of the microorganisms in the experimental soils. Higher bacterial counts recorded in amended bioremediated soils might be as a result of high quantities of nitrogen and phosphorus recorded in poultry droppings and cow dung, which are essential nutrients needed for bacterial biodegradative activities (Abioye $\boldsymbol{e t} \boldsymbol{a l}$. 2010; Baruah and Das, 2014; Adeleke et al., 2016).

There was a progressive reduction in the total petroleum hydrocarbon during remediation in all the bioremediated soil with bacterial cocktail (BC), Poultry droppings (PD) and cow dung (CD) compared to unamended soil (control) and autoclaved remediated soil with $5 \% \mathrm{NaN}_{3}$. Although microorganisms are present in contaminated soil, their numbers might not be sufficient to initiate remediation of contaminated sites (Nwogu et al., 2015). The growth and activities of HUB must be stimulated and require essential nutrients like nitrogen, phosphorus, and carbon as building blocks. This study shows that the rate of biodegradation of diesel oil in soil bioremediated with $\mathrm{BC}+10 \%(\mathrm{PD}+\mathrm{CD})$ had the highest total petroleum hydrocarbon (TPH) degradation of $96.80 \%$ at the end of remediation (day 84).

This is consistence with kinetic parameters observed in this study (Table 3 ) which show that the degradation rates of diesel in soil remediated with $\mathrm{BC}+10 \%$ $(\mathrm{PD}+\mathrm{CD})$ was higher than other treatments. This may be due to the synergetic effect of cow dung and poultry droppings resulting in high percentage of nutrient especially nitrogen and phosphorus which are needed for optimum growth and performances of HUB thus facilitating the synthesis of the necessary enzymes needed to break down the petroleum hydrocarbon contaminants (Gorban et al. 2011; Okoh, 2013). However, the rate of hydrocarbon degradation in autoclaved remediated soil with $5 \% \mathrm{NaN}_{3}$ was lower $(18.42 \%)$ than even the unamended soil (control) and this may be due to the antimicrobial nature of $\mathrm{NaN}_{3}$ (Rahmoun $\boldsymbol{e}$ al., 2013), which limit the biodegradative activities and growth of HUB in soil. Although, there was slow and gradual decrease in the TPH concentration in unamended soil compared to the other amended bioremediated soils. This might be attributed to other processes such as volatilization, adsorption, and abiotic factors (temperature), which have been reported to contribute to decrease in TPH concentration (Nwogu, et al., 2015). Similarly, the control soil was able to record higher TPH degradation than the autoclaved soil remediated with $5 \% \mathrm{NaN}_{3}$ because autoclaving also could inhibit the growth of the organisms and reduce the rate of biodegradation whereas unamended soil (control) contains some level of bacteria which enhance biodegradation of hydrocarbon.
Gas chromatography and mass spectrometry (GCMS) are the methods used for identification of compounds in oil compounds. In this study, gas chromatography with mass spectrometer was used to provide insight into the hydrocarbon composition of diesel contaminated soil after bioremediation. GCMS chromatogram show significant hydrocarbon degradation in all sample tested compared to natural diesel oil and the chromatograms of the bio-remediated soil revealed some peaks.

Soil bio-remediated with bacterial cocktail $(\mathrm{BC})+10 \%$ poultry dropping $(\mathrm{PD})$ and cow dung $(\mathrm{CD})$ had the highest reduction in individual hydrocarbons odd molecular weight of n- alkane $\left(\mathrm{C}_{11}-\mathrm{C}_{31}\right)$, carboxylic acid $\left(\mathrm{C}_{2} \mathrm{H}_{3} \mathrm{O}-\mathrm{C}_{23} \mathrm{H}_{44} \mathrm{O}_{3}\right)$, naphthalene and akyl group of naphthalene $\left(\mathrm{C}_{10} \mathrm{H}_{8}-\mathrm{C}_{15} \mathrm{H}_{28}\right)$, aromatic and polycyclic aromatic compounds compared to other bio-remediated soil at the end of study period (day 84). This result correlates with total petroleum hydrocarbon (TPH) degraded $(96.80 \%)$ and kinetic parameter observed in this study and it is similar to Dadrasnia and Agamuthu (2013). This may be due to the ability of the organisms to secrete enzymes (dioxygenase, cytochrome $\mathrm{P}_{450}$ ) capable of degrading the hydrocarbon compounds and also to the synergistic effect of cow dung and poultry droppings containing high percentage of nutrient especially nitrogen and phosphorus needed for optimum growth and developments (Gorban et al., 2011; Nilanjana and Preethy, 2011).

\section{CONCLUSION}

In this study, Hydrocarbon utilizing bacteria isolated from contaminated soil were Micrococcus luteus strain trpE16, Bacillus subtilis strain DNK UT 02, Rhodococcus sp, Staphylococcus sp, and Pseudomonas sp. Micrococcus luteus straintrpE16 and Bacillus subtilis strain DNK UT 02 were used as bacterial cocktail as a result of their higher ability to utilize diesel oil as source of carbon and energy than other organisms that were isolated. Bioremediation of diesel contaminated soil by bacterial cocktail (BC) and organic wastes (cow dung and poultry droppings) recorded above $90 \%$ of diesel degradation after of 84 days. However, soil bioremediated with $\mathrm{BC}+10 \%$ Poultry droppings (PD) + Cow dung $(\mathrm{CD})$ recorded the highest bacterial counts.

\section{REFERENCES}

Abioye, O.P., Abdul-Aziz, A., \& Agamuthu, P. (2010). Enhanced Biodegradation of Used Engine oil in soil amended with organic wastes. Water, Air and Soil pollution, 209, 173-179. http://dx.doi.org/10.1007/s11270-009-0189-3

Abioye, O. P., Agamuthu, P., \& AbdulAziz, A. R. (2012). Biodegradation of Used Motor Oil in Soil Using Organic Waste Amendments. Biotechnology Research International, 10, 1-8. http://dx.doi.org/10.1155/2012/587041

Adaba, C. S. (2013). Effects of particle size distribution on bioremediation of crude oil polluted sandy soil. Nigeria Journal of Technology, 32(3), 1-15.

Adeleke, I. F., Esther, B. B., \& Clement, A. F. (2016). Comparative bioremediation of crude oil contaminated soil samples using activated soil and activated cow dung. Sky Journal of Microbiology Research, 4(4), 021-030.

Adesodun, J. K., \& Mbagwu, J.S. (2008). Biodegradation of waste lubricating oil in a tropical alfsoil as mediated by animal droppings. Bioresource Technology, 99(13), 5659-5665. http://dx.doi.org/10.1016/j.biortech.2007.10.031

Akpoveta, O., Egharevba, F., Medjor, O., Osaro K., \& Enyemike, E. (2011) Microbial Degradation and its Kinetics on Crude Oil Polluted Soil. Research Journal of Chemical Sciences, 11(6), 8-14.

Baruah, D., \& Das, N. J. (2014). Hydrocarbon-degrading bacteria diversity in soils contaminated with diesel oil. Industrial pollution control, 16(3), 308-314.

Chen, M., Xu, P., Zeng, G., Yang, C., Huang, D., \& Zhang, J. (2015). Bioremediation of soils contaminated with polycyclic aromatic hydrocarbon, petroleum, pesticides, chlorophenols and heavy metals by composting Applications, microbes and future research needs. Biotechnology Advances, 33(1), 745-755.

Castro-Gutiérrez, V. M., Rodríguez-Rodríguez, C. E., \& Vargas-Azofeifa, I (2012). Bioaugmentation for soil bioremediation. International Journal Environmental, 21 (6), 345-352.

Dadrasnia, A., \& Agamuthu, P. (2013). Dynamics of diesel fuel degradation in contaminated soil using organic wastes. International Journal Environmental Science Technology, 10, 769-778. http://dx.doi.org/10.1007/s13762-013-0224-1

Ebere, J. U., Wokoma, E. C., \& Wokocha, C. C. (2011). Enhanced Remediation of a Hydrocarbon Polluted Soil. Research Journal of Environmental and Earth Sciences, 3(2), 70-74.

Gorban, A.N., Pokidysheva, I., Smirnova, E.V., \& Tyukina, T.A. (2011). Law of the minimum paradoxes," Bulletin of Mathematical Biology, 73 (9), 2013-2044. http://dx.doi.org/10.1007/s11538-010-9597-1

Henrik, C. (2004). Methods in Practical Laboratory Bacteriology, CRC Press: London. 201-220.

Ibiene, A. A., Orji, F. A., Ezidi, C. O., \& Egwobia, C. L. (2011). Bioremediation of Hydrocarbon Contaminated Soil in the Niger Delta using Spent Mushroom Compost and other Organic wastes. Nigeria Journal of Agriculture, Food and Environment, 7(3), 1-7. 
Nilanjana, D., \& Preethy, C. (2011). Microbial degradation of petroleum hydrocarbon contaminants: An overview: Biotechnology Research international, 20 (11). 1-13. http://dx.doi.org/10.4061/2011/941810

Nwogu, T. P. Azubuike, C. C., \& Ogugbue, C. J. (2015). Enhanced Bioremediation of Soil Artificially Contaminated with Petroleum Hydrocarbons after Amendment with goat manure, International Journal of Biomedical Research, 3(1), 45-51. http://dx.doi.org/10.1155/2015/657349

Odu, C. I., Amadi, E. N., \& Okolo, J. C. (2015). Effect of soil treatments containing poultry manure on diese oil degradation in a sandy loam soil. Applied Ecology Environment, 3 (1), 147-159.

Olabemiwo, O. M., Adediran, G. O., Adekola, F. A., Adelowo, O. O., \& Olajire, A. A. (2014). Biodegradation of hydrocarbon compounds in Agbabu natural bitumen. African Journal of Biotechnology, 13(11), 1257-1264.

Okoh, A. I. (2013). Biodegradation of Bonny light crude oil in soil microcosm by some bacterial strains isolated from oil flow stations saver pits in Nigeria. African Journal Biotechnology, 12(5), 104-201.

Rahmoun, E. A., Nadjib, M., \& Mohammed, A. H. (2013). Antimicrobial Activities of the Henna Extract and Some Synthetic Naphthoquinones Derivatives. American Journal of Medical and Biological Research, 1(1), 16-22. http://dx.doi.org/10.12691/ajmbr-1-1-3

Tariq, M., Hemighaus, K., Hoekman, J., Horn, A., Gibbs, M., Ingham, L., \& Jossens, D. (2016). Bioremediation of crude oil- bearing soil: effect of Rhamnolipid addition to soil toxicity and crude oil biodegradation efficiency. International Journal of Environment, 11(2), 1181-1190.

Yeung, P.Y., Johnson, R. L., \& Xu, J. G. (1997). Biodegradation of petroleum hydrocarbons in soil as affected by heating and forced aeration. Journal of Environmental Ouality, 26, 1511-1576. http://dx.doi.org/10.2134/jeq1997.00472425002600060009x. 